\title{
Bronchoalveolar Lavage. Technical Notes
}

\author{
V. Poletti, G. Casoni, C. Ravaglia, M. Romagnoli, S. Tomassetti
}

Monaldi Arch Chest Dis 2011; 75: 1, 42-43.

Keywords: Bronchoalveolar lavage, Patient safety, Diagnostic role, Immuno-compromised, Immuno-competent.

Dipartimento di Malattie del Torace, Ospedale Morgagni-Pierantoni, Forlì, Italy.

Correspondence: Prof. Venerino Poletti, Dipartimento di Malattie del Torace, Ospedale Morgagni-Pierantoni, Via Forlanini 34, 47100 Forlì, Italy; e-mail: venerino.poletti@gmail.com

Bronchoalveolar lavage (BAL) should be performed with at least $100 \mathrm{ml}$. Small volume lavage (less than $20 \mathrm{ml}$ ) in a main stem bronchus or a segmental bronchus recovered more epithelial cells and neutrophils while a lavage volume of 20-100 $\mathrm{ml}$ in a segmental bronchus recovered more lymphocytes, alveolar macrophages, albumin, $\mathrm{IgG}$ and alpha 1-antitrypsin. Boluses of 10, 20, and $50 \mathrm{ml}$ were associated with a recovery of $22 \%, 10 \%$, and $5 \%$ of neutrophils, respectively [1] (Evidence: Ia).

BAL fluid should be analysed in specialised laboratories and microbiological investigations, cytologycal analysis and cytofluorimetric procedures are considered as the more appropriate workup [2] (Level of evidence: Ia).

\section{Recommendation}

- BAL should be performed with at least $100 \mathrm{ml}$ of saline solution (Grade A).

\section{Patient safety}

Patients submitted to BAL may experience hypoxia (generally transient) during bronchoscopy. Fever may appear a few hours later in up to $30 \%$ of cases. Other complications are extremely rare also in immunocompromised hosts or in mechanically ventilated patients [2-5] (Level of evidence: Ia).

\section{Recommendation}

- BAL is a safe procedure also in immunocompromised hosts and in mechanically ventilated patients (Grade A).

\section{Diagnostic role}

The diagnostic role of BAL is fundamental in patients with pulmonary infiltrates and compromised immune systems. Diagnoses feasible on the basis of BAL findings in this clinical setting are reported in Table 1. Non-invasive and bronchoscopic procedures are useful techniques for the diagnosis of pulmonary infiltrates in immunocompromised patients. FibroBronchial ASpirate (FBAS), TracheoBronchial ASpirate (TBAS) and BAL have the highest diagnostic yield and impact on therapeutic decisions [4-8].

Table 1. - Diagnoses feasible on the basis of BAL findings in immunocomprimised patients

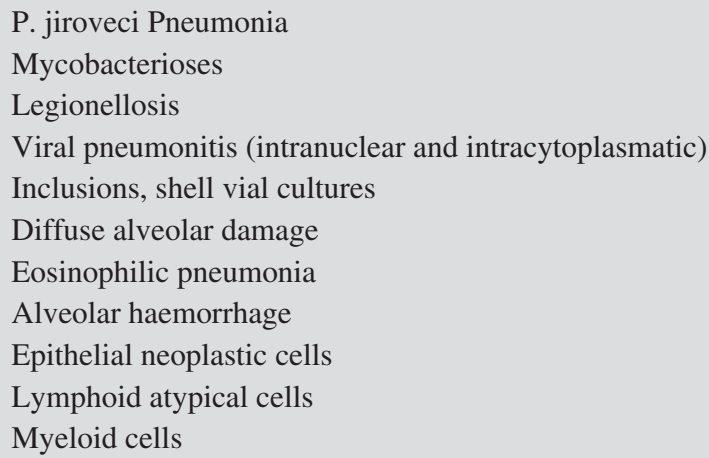

(Level of evidence Ia)

\section{Recommendation}

- BAL is a first choice diagnostic procedure in immuno-compromised hosts (Grade A).

In immuno-competent patients BAL is diagnostic in rare disorders such as alveolar proteinosis, Langerhans cell histiocytosis, eosinophilic pneumonia; in these cases this procedure may spare a biopsy. In more common diffuse interstitial or alveolar pneumonitis it is part of the diagnostic work up $[9,10]$ (Level of evidence: IIa).

\section{Recommendation}

- BAL should be part of the diagnostic workup in immuno-competent hosts with diffuse parenchymal lung disease (Grade B). 


\begin{tabular}{|c|c|}
\hline & Summary of Recommendations \\
\hline & $\begin{array}{l}\text { BAL should be performed with at least } \\
\mathbf{1 0 0} \mathrm{ml} \text { of saline solution (Grade A). } \\
\text { BAL is a safe procedure also in im- } \\
\text { munocompromised hosts and in me- } \\
\text { chanically ventilated patients (Grade A). } \\
\text { BAL is a first choice diagnostic pro- } \\
\text { cedure in immunocompromised } \\
\text { hosts (Grade A). } \\
\text { BAL should be part of the diagnostic } \\
\text { workup in immuno-competent hosts } \\
\text { with diffuse parenchymal lung dis- } \\
\text { ease (Grade B). }\end{array}$ \\
\hline & References \\
\hline & $\begin{array}{l}\text { Lam S, Leriche JC, Kijek K, et al. Effect of bronchial } \\
\text { lavage volume on cellular and protein recovery. Chest } \\
\text { 1985; 88: 856-859. }\end{array}$ \\
\hline & $\begin{array}{l}\text { Van Vyve T, Chanez P, Lacoste JY, et al. Comparison } \\
\text { between bronchial and alveolar samples of Bron- } \\
\text { choalveolar lavage fluid in asthma. Chest 1992; 102: } \\
\text { 356-361. } \\
\text { Technical recommendations and guidelines for bron- } \\
\text { choalveolar lavage (BAL). Report of the European So- } \\
\text { ciety of Pneumology Task Group. Eur Respir J 1989; 6: } \\
\text { 561-585. }\end{array}$ \\
\hline
\end{tabular}

4. Kasow KA, King E, Rochester R, et al. Diagnostic yield of bronchoalveolar lavage is low in allogeneic hematopoietic stem cell recipients receiving immunosuppressive therapy or with acute graft-versus-host disease: the St. Jude experience, 1990-2002. Biol Blood Marrow Transplant 2007; 13: 831-837.

5. Peikert T, Rana S, Edell ES. Safety, diagnostic yield, and therapeutic implications of flexible bronchoscopy in patients with febrile neutropenia and pulmonary infiltrates. Mayo Clin Proc 2005; 80: 1414-1420.

6. Bulpa PA, Dive AM, Mertens L, et al. Combined bronchoalveolar lavage and transbronchial lung biopsy: safety and yield in ventilated patients. Eur Respir $J$ 2003, 21: 489-494.

7. Poletti V, Chilosi M, Olivieri D, et al. Diagnostic invasive procedures in diffuse infiltrative lung Diseases. Respiration 2004; 71: 107-119.

8. Rano A, Augusti C, Jimenez P, et al. Pulmonary infiltrates in non-HIV immunocompromised patients: a diagnostic approach using non-invasive and bronchoscopic procedures. Thorax 2001; 56: 379-387.

9. Joos L, Chhajed PN, Wallner J, et al. Pulmonary infections diagnosed by BAL: a 12-year experience in 1066 immunocompromised patients. Respir Med 2007; 101: 93-97.

10. Poletti V, Cazzato S, Minicuci N, Zompatori M, Burzi M, Schiattone ML. The diagnostic value of bronchoalveolar lavage and transbronchial lung biopsy in cryptogenic organizing pneumonia. Eur Respir J 1996; 12: 2513-2516.

11. Ryu YJ, Chung MP, Han J, et al. Bronchoalveolar lavage in fibrotic idiopathic interstitial pneumonias. Respir Med 2007, 101: 655-660.

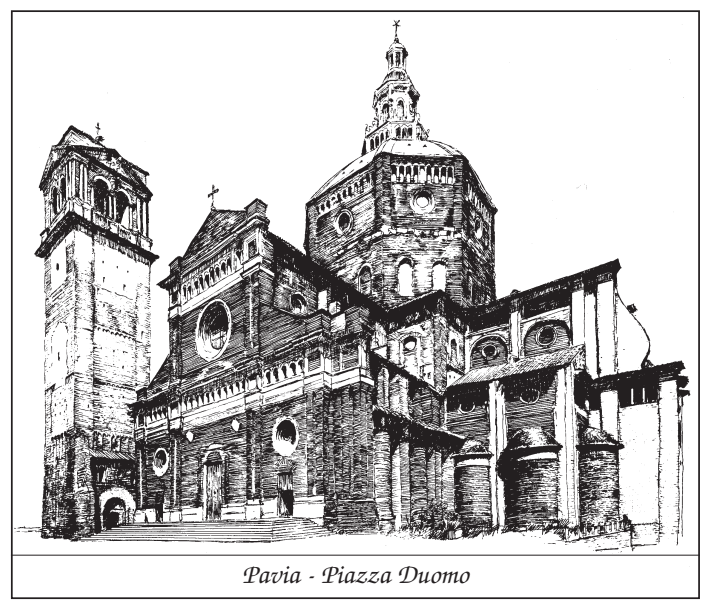

